\title{
Phenotypic Profile of Rh and Kell Blood Group Systems among Blood Donors in Cote d'Ivoire, West Africa
}

\author{
L. Siransy Bogui, ${ }^{1,2}$ B. Dembele, ${ }^{1,3}$ Y. Sekongo, ${ }^{1,2}$ S. Abisse, ${ }^{1,2}$ S. Konaté, ${ }^{1}$ and M. Sombo ${ }^{2,4}$ \\ ${ }^{1}$ National Blood Transfusion Center, 52 boulevard de Marseille, BP 15 Abidjan, Cote d'Ivoire \\ ${ }^{2}$ Laboratory of Immunology, UFR of Medical Sciences, BP 34 Abidjan 01, Cote d'Ivoire \\ ${ }^{3}$ Laboratory of Immunology, UFR of Pharmaceutical and Biological Sciences, BP 34 Abidjan 01, Cote d'Ivoire \\ ${ }^{4}$ Hospital and University Centre of Cocody, BP 1843 Abidjan 08, Cote d'Ivoire
}

Correspondence should be addressed to L. Siransy Bogui; 1siransy@gmail.com

Received 24 May 2014; Accepted 25 August 2014; Published 24 September 2014

Academic Editor: Silvano Wendel

Copyright (C) 2014 L. Siransy Bogui et al. This is an open access article distributed under the Creative Commons Attribution License, which permits unrestricted use, distribution, and reproduction in any medium, provided the original work is properly cited.

Few countries in sub-Saharan Africa make systematic searches for antigens C, c, E, and e of the Rh and Kell system antigens in the donor and recipient, thereby exposing transfused patients. Purpose and Objectives. In this paper, we propose to determine the red cell Rh and Kell blood groups among blood donors from traditional techniques to improve medical care of transfused patients. This study will allow us to assess the frequency of blood group antigens in these systems. Study Design and Methods. We carried out a study on the red cell typing in the blood donor population of the National Blood Transfusion Center in Abidjan. This study was performed on 651 blood donors. Results. For the Rh system, the antigen frequencies of D, c, e, C, and E are, respectively, 92.93\%, $99.85 \%, 99.85 \%, 21.97 \%$, and $13.82 \%$. K antigen is found in $0.77 \%$ of donors. Discussion and Conclusion. Although the frequencies of the most immunogenic antigens are lower than in the white race, lack of preventive measures makes the immunological risk high in Africa. Furthermore, Africa is full of specificities that are important to note for a better care of our patients.

\section{Introduction}

In Cote d'Ivoire and in other African countries [1,2], most of transfusions are done only based on $\mathrm{ABO}$ and $\mathrm{D}$ antigens. Although blood transfusions can save life, they are not without risk. Blood transfusion can carry immediate or delayed immunological risks; the most common and most serious is the hemolytic transfusion reaction by antibody incompatibility. Knowledge about the frequency of red cells antigens phenotypes in Ivorian population is important for the creation of a donor data bank and to minimize risks of alloimmunization. This requires the determination of the immunological characteristics of blood products and blood recipients by performing immunohematology analysis such as phenotyping in $\mathrm{Rh}$ and Kell blood group systems. Currently, there are thirty-three major blood group systems [3], but analyses recommended in the usual situation are $\mathrm{ABO}, \mathrm{Rh}$, and Kell typing and detecting red cell antibodies.

Unfortunately, in sub-Saharan countries, few practice this systematic search for antigens $\mathrm{C}, \mathrm{c}, \mathrm{e}, \mathrm{E}$, and $\mathrm{K}$ in the donor and recipient, thereby exposing the transfused patient to high risk of alloimmunization [4].

Very few studies are available, reporting antigens frequencies of Rh and Kell blood groups in sub-Saharan countries.

This study is the first report on the frequency of blood groups system Rh and Kell in blood donors in Cote d'Ivoire. This work will perform $\mathrm{Rh}$ and Kell red cell typing among blood donors by traditional techniques to implement this into the routine for blood donors and recipients. It also allows us to determine the frequency of the major Rh and Kell blood group antigens and phenotypes commonly found among blood donors from Cote d'Ivoire to improve transfusion practices.

\section{Materials and Methods}

It was a retrospective study conducted at the Laboratory of Immunohaematology of the National Blood Transfusion Center of Abidjan, the capital of Cote d'Ivoire. 
2.1. Blood Donors. We analyzed grouping data in $\mathrm{Rh}$ and Kell blood group systems from 651 volunteer regular blood donors coming to the national blood on one year. The blood donors have an age range from 18 to 60 years.

Those excluded from donating blood fell within the following categories:

(i) taking drugs for high blood pressure or heart failure;

(ii) having $\mathrm{Hb}$ below $11 \mathrm{~g} / \mathrm{dL}$ (for females) or $12 \mathrm{~g} / \mathrm{dL}$ (for males);

(iii) testing positive for $\mathrm{HBsAg}, \mathrm{HCV}$, and $\mathrm{HIV}$ antibodies and syphilis;

(iv) having had jaundice, liver disease, epilepsy, diabetes, duodenal or gastric ulcer, asthma, tuberculosis, or other pathology;

(v) taking self-injected drugs;

(vi) having sickle cell disease;

(vii) being a prostitute and/or homosexual;

(viii) having severe weight loss within the last six months.

2.2. Methods. For optimal results, the determination was performed using a tube freshly drawn into ethylenediaminetetraacetate according to manufacturer's instructions. The techniques are direct agglutination of the antigens with slide technique for $\mathrm{Rh}$ system antigens and indirect antiglobulin technique by tube technique for Kell system antigens. Rh phenotyping was done using five monoclonal monospecific antisera: anti-D, anti-E, anti-C, anti-c, and anti-e while Kell phenotyping was performed with anti-K according to manufacturer's instructions. All reagents were supplied by Orgenics PBS, Eurobio.

Positive and negative control red cells and Coombs' control cells were also performed as controls. Data were entered and analyzed with Epi Info version 6.1.

\section{Results}

We determined blood group antigens in 651 donors with sex ratio 3.6 in favor of men.

605 blood donors representing 92.93\% of the blood donors were found to be $\mathrm{RhD}$ positive while 46 blood donors representing 7.07 were found to be $\mathrm{RhD}$ negative (Figure 1).

The $\mathrm{c}$ and e antigens have the highest frequency with 99.83\%. C and $\mathrm{E}$ antigen were less frequent with $21.97 \%$ and $13.82 \%$, respectively (Table 1 ).

Seven phenotypes were detected among the blood donors (Table 2). The most frequent phenotype among the RhD positive was $\mathrm{R}_{0} \mathrm{r} 65.12 \%$ followed by $\mathrm{R}_{1} \mathrm{r} 20 \%$ and $\mathrm{R}_{2} \mathrm{r} 12.73 \%$. Among the $\mathrm{RhD}$ negative, the most frequent was $\operatorname{rr}(80.43 \%)$.

In the Kell blood group system, 5 blood donors (0.77\%) were typed as $\mathrm{K}$ antigen positive and $645(98.08 \%)$ as $\mathrm{k}$ antigen positive antigens. Accordingly, the $\mathrm{K}-\mathrm{k}+$ phenotype was the most common in these donors (98.92\%).



Blood donors, $\mathrm{RhD}$ positive

Blood donors, $\mathrm{RhD}$ negative

FIgURE 1: Prevalence of $\mathrm{RhD}$ antigen in blood donors.

\section{Discussion}

Our study focused on 651 regular and volunteer blood donors who have made donations at the National Blood Transfusion Center. The techniques used were the traditional techniques of agglutination on slide or in tube (indirect antiglobulin). Although recent years have been marked by the appearance of microtechnology, we wanted to show that, even with traditional techniques, such typing can be performed in a department with limited resources. The findings in our study will introduce plan for better care of the patients.

4.1. The Rh System. After ABO blood group, the Rh system is the most important in transfusion medicine. In Cote d'Ivoire, the blood transfusions are done only regarding $\mathrm{ABO}$ and $\mathrm{RhD}$ antigens exposing patients to high alloimmunization. Akre [4] found that $62.8 \%$ of patients suffering from sickle cell disease and transfused were immunized against $\mathrm{Rh}$ and Kell antigens systems. $\mathrm{Rh}$ was involved in $44.44 \%$ while Kell was involved in $27.78 \%$ in sickle cell patients transfused against 38\% for both in France [12]. The most frequent alloantibodies were anti-E, anti-C, and anti-KEL1 developed after transfusion of standard red cell units.

In our study, the frequency of D antigen was $92.93 \%$. This is comparable with the findings in the north of Cote d'Ivoire [3] and in the black population [13]. It is higher in other sub-Saharan Africa countries [1,2,5] and non-sub-Saharan Africa countries [7-10] (Table 3). Frequencies are lower in the US, France, and Nigeria where the authors found respective prevalence of $85.4 \%, 85 \%$, and $81.5 \%[6,11,12]$.

The prevalence of the $\mathrm{RhD}$ negative is $7.7 \%$. These results agree with the work of Seka [14] who found $7.28 \%$ and the work of Cabannes $[15,16]$ that quoted values ranging from 1.70 to $9.3 \%$ in sub-Saharan Africa.

The frequencies of $\mathrm{c}$ and $\mathrm{e}$ antigens in our study are high $(99,85 \%)$ (Table 1) while the frequencies of $\mathrm{C}$ and $\mathrm{E}$ antigens are lower, respectively, $21.97 \%$ and $13.82 \%$. Among whites, European, and Asian people, e antigen is the most popular, and then comes $\mathrm{C}$ antigen [17]. As regards to $\mathrm{C}$ and $\mathrm{E}$ antigens, frequencies are higher than in our study (C 70\% and E 26\%) $[5,9,12,17]$. Among RhD negative donors, E antigen is absent. 
TABLE 1: Rh and Kell antigens frequency among 651 Ivorian blood donors.

\begin{tabular}{|c|c|c|c|c|c|c|}
\hline \multirow{2}{*}{ Antigens } & \multicolumn{2}{|c|}{ RhD negative donors } & \multicolumn{2}{|c|}{ RhD positive donors } & \multicolumn{2}{|c|}{ Total } \\
\hline & $n$ & $\%$ & $n$ & $\%$ & $n$ & $\%$ \\
\hline $\mathrm{c}+$ & 46 & 100 & 604 & 99,83 & 650 & 99,85 \\
\hline e+ & 46 & 100 & 604 & 99,83 & 650 & 99,85 \\
\hline $\mathrm{C}+$ & 9 & 19,57 & 134 & 22,15 & 143 & 21,97 \\
\hline$\underline{E}+$ & 0 & 0 & 90 & 14,88 & 90 & 13,82 \\
\hline$\overline{\mathrm{k}}$ & & & & & 650 & 99,84 \\
\hline $\mathrm{K}$ & & & & & 5 & 0,77 \\
\hline $\mathrm{Kp}^{\mathrm{a}}$ & & & & & 4 & 0,61 \\
\hline $\mathrm{Kp}^{\mathrm{b}}$ & & & & & 539 & 82,80 \\
\hline
\end{tabular}

TABLE 2: Rh and Kell phenotypes frequencies in Cote d'Ivoire blood donors $(n=651)$.

\begin{tabular}{|c|c|c|c|c|c|}
\hline \multirow[b]{2}{*}{ Antigens } & \multirow[b]{2}{*}{ Phenotypes } & \multicolumn{2}{|c|}{ Genotypes } & \multirow[b]{2}{*}{ Number } & \multirow[b]{2}{*}{ Frequency \% } \\
\hline & & Wiener & $\begin{array}{c}\text { Fischer } \\
\text { race }\end{array}$ & & \\
\hline Rh positive donors & & & & 605 & \\
\hline $\mathrm{D}+\mathrm{C}-\mathrm{E}-\mathrm{c}+\mathrm{e}+$ & $\mathrm{R}_{0} \mathrm{r}$ & $\begin{array}{c}\mathrm{R}^{0} \mathrm{r} \\
\mathrm{R}^{0} \mathrm{R}^{0}\end{array}$ & $\begin{array}{l}\text { Dce/dce } \\
\text { Dce/Dce }\end{array}$ & 394 & 65,12 \\
\hline $\mathrm{D}+\mathrm{C}+\mathrm{E}-\mathrm{c}+\mathrm{e}+$ & $\mathrm{R}_{1} \mathrm{r}$ & $\begin{array}{c}\mathrm{R}^{1} \mathrm{r} \\
\mathrm{R}^{1} \mathrm{R}^{0} \\
\mathrm{R}^{0} \mathrm{r}^{\prime}\end{array}$ & $\begin{array}{c}\mathrm{DCe} / \mathrm{Dce} \\
\mathrm{DCe} / \mathrm{Dce} \\
\mathrm{Dce} / \mathrm{dCe}\end{array}$ & 121 & 20,00 \\
\hline $\mathrm{D}+\mathrm{C}-\mathrm{E}+\mathrm{c}+\mathrm{e}+$ & $\mathrm{R}_{2} \mathrm{r}$ & $\begin{array}{c}\mathrm{R}_{2} \mathrm{r} \\
\mathrm{R}^{2} \mathrm{R}^{0}\end{array}$ & $\begin{array}{l}\text { DcE/dce } \\
\text { DcE/Dce }\end{array}$ & 77 & 12,73 \\
\hline $\mathrm{D}+\mathrm{C}+\mathrm{E}+\mathrm{c}+\mathrm{e}+$ & $\mathrm{R}_{1} \mathrm{R}_{2}$ & $\begin{array}{l}\mathrm{R}^{1} \mathrm{R}^{2} \\
\mathrm{R}^{1} \mathrm{r}^{\prime \prime} \\
\mathrm{R}^{2} \mathrm{r}^{\prime} \\
\mathrm{R}^{\mathrm{Z}} \mathrm{r} \\
\mathrm{R}^{0} \mathrm{R}^{\mathrm{z}} \\
\mathrm{R}^{0} \mathrm{r}^{\mathrm{y}}\end{array}$ & $\begin{array}{c}\mathrm{DCe} / \mathrm{DcE} \\
\mathrm{DCe} / \mathrm{dcE} \\
\mathrm{DcE} / \mathrm{dCe} \\
\mathrm{DCE} / \mathrm{dce} \\
\text { Dce/DCE } \\
\text { Dce/dCE }\end{array}$ & 12 & 7,00 \\
\hline $\mathrm{D}+\mathrm{C}+\mathrm{E}+\mathrm{c}-\mathrm{e}-$ & $\mathrm{R}_{\mathrm{z}} \mathrm{R}_{\mathrm{z}}$ & $\begin{array}{l}\mathrm{R}^{\mathrm{z}} \mathrm{R}^{\mathrm{z}} \\
\mathrm{R}^{\mathrm{z}} \mathrm{r}^{\mathrm{y}}\end{array}$ & $\begin{array}{l}\mathrm{DCE} / \mathrm{DCE} \\
\mathrm{DCE} / \mathrm{dCE}\end{array}$ & 1 & 0,17 \\
\hline Rh negative donors & & & & 46 & \\
\hline $\mathrm{D}-\mathrm{C}-\mathrm{E}-\mathrm{c}+\mathrm{e}+$ & $\mathrm{rr}$ & $\mathrm{rr}$ & dce/dce & 37 & 80,43 \\
\hline $\mathrm{D}-\mathrm{C}+\mathrm{E}-\mathrm{c}+\mathrm{e}+$ & $\mathrm{r}^{\prime} \mathrm{r}$ & $r^{\prime} r$ & dCe/dce & 9 & 19,57 \\
\hline \multicolumn{6}{|l|}{ Kell } \\
\hline $\mathrm{K}-\mathrm{k}+$ & & & & 645 & 99.08 \\
\hline $\mathrm{K}+\mathrm{k}+$ & & & & 5 & 0.77 \\
\hline $\mathrm{K}-\mathrm{k}-(\mathrm{k} 0)$ & & & & 1 & 0,15 \\
\hline
\end{tabular}

TABLE 3: Antigens frequencies of Rh blood group compared with published results.

\begin{tabular}{|c|c|c|c|c|c|c|c|c|c|c|c|c|}
\hline Antigen & $\begin{array}{c}\text { Our } \\
\text { study } \\
(n)\end{array}$ & $\begin{array}{c}\text { Our } \\
\text { study } \\
(\%)\end{array}$ & $\begin{array}{c}\text { North } \\
\text { Cote } \\
\text { d'Ivoire } \\
{[3]}\end{array}$ & $\begin{array}{c}\text { Mauritania } \\
{[1]}\end{array}$ & $\begin{array}{c}\text { Guinea } \\
\text { [5] }\end{array}$ & $\begin{array}{c}\text { Cameroun } \\
{[2]}\end{array}$ & $\begin{array}{c}\text { Nigeria } \\
{[6]}\end{array}$ & $\begin{array}{c}\text { Antananarivo } \\
{[7]}\end{array}$ & $\begin{array}{c}\text { Morocco } \\
{[8]}\end{array}$ & $\begin{array}{c}\text { India } \\
{[9]}\end{array}$ & $\begin{array}{l}\text { Iran } \\
{[10]}\end{array}$ & $\begin{array}{l}\text { USA } \\
{[11]}\end{array}$ \\
\hline $\mathrm{D}+$ & 605 & 92,93 & 92.5 & 94,2 & 95,9 & 95 & 81,5 & 98,9 & 90,5 & 94,4 & 90,2 & 85.4 \\
\hline D- & 46 & 7,70 & 7.5 & 5,77 & 4,06 & 6 & 18,5 & 1,1 & 9,5 & 5,64 & 9,8 & 14.6 \\
\hline $\mathrm{c}+$ & 650 & 99,85 & & & & 97,5 & & & & & 73,9 & \\
\hline e+ & 650 & 99,85 & & & & 97,5 & & & & & 97,9 & \\
\hline $\mathrm{C}+$ & 143 & 21,97 & & & & 95 & & & & & 75,9 & \\
\hline $\mathrm{E}+$ & 90 & 13,82 & & & & 92,5 & & & & & 29,5 & \\
\hline
\end{tabular}


In the Rh system, seven phenotypes on eighteen known [13] were identified in our population (Table 2). The phenotype most frequently encountered is the phenotype $R_{0} r$ (65.12\%) regarding $\mathrm{RhD}$ positive blood donors and $\mathrm{rr} 80.43 \%$ among $\mathrm{RhD}$ negative blood donors. This profile is different from that observed in the whites where the phenotype $R_{1} r$ or $R_{1} R_{1}$ is the most popular $[12,13] . R_{z} R_{z}$ was found in one donor.

4.2. The Kell System. The importance of this system is due to the $\mathrm{K}$ antigen, which has strong immunogenicity. It is among the most immunogenic system after the Rh system.

In the Kell system, $\mathrm{k}$ antigen was found in $98.92 \%$ of blood donors which is comparable with frequency in whites.

The prevalence of $\mathrm{K}$ antigen was found to be $0.92 \%$ of donors enrolled in the study, contrary to France where 9\% of individuals are $\mathrm{K}+[12]$ and to Germany where $4 \%$ express the $\mathrm{K}$ antigen [18].

The most common phenotype was $\mathrm{K}-\mathrm{k}+$ which is also common in white people. The antigens $\mathrm{Kp}^{\mathrm{a}}$ and $\mathrm{Kp}^{\mathrm{b}}$ were found, respectively, at frequencies of $0.61 \%$ and $82.80 \%$ in our sample, against $0.2 \%$ and $99.8 \%$ in whites [17].

\section{Conclusion}

Immunohematology data on blood donors are very few in West Africa. The $\mathrm{ABO}$ and $\mathrm{D}$ antigens are the main examination; other investigations are not performed.

Furthermore, Africa is full of its own specificities that are important to note for better care of patients by improving routine tests like phenotyping red cells, screening, and identifying red cells antibodies.

Research in that field should benefit from common work from West Africa national blood transfusion centers to enhance safety in transfusion medicine.

\section{Conflict of Interests}

The authors declare that there is no conflict of interests regarding the publication of this paper.

\section{References}

[1] C. T. Hamed, M. A. Bollahi, I. Abdelhamid et al., "Frequencies and ethnic distribution of $\mathrm{Rh}(\mathrm{D})$ blood group in Mauritania," International Journal of Immunogenetics, vol. 39, pp. 151-154, 2012.

[2] S. H. Mandengue, G. Lehman Leopold, P. Assomo-Ndemba, and M. Mbangue, "Distribution des antigènes des systèmes $\mathrm{ABO}$, rhésus, Kell, MNSs et Duffy chez des drepanocytaires et donneurs de sang bénévoles à Douala (Cameroun): risques de réactions transfusionnelles," Médecine d'Afrique Noire, vol. 50, no. 1, pp. 22-24, 2003.

[3] A. Santovito, C. Burgarello, P. Cervella et al., "Erythrocyte polymorphisms in five ethnic groups of Northern Côte d'Ivoire," International Journal of Immunogenetics, vol. 36, no. 3, pp. 189191, 2009.
[4] D. P. Akre, J. Seka-Seka, S. R. Dasse et al., "Alloimmunisation anti érythrocytaire post transfusionnelle chez les drépanocytaires au CHU de Cocody Abidjan," International Journal of Pharma and Bio Sciences, vol. 9, no. 2, pp. 64-70, 2008.

[5] A. Loua, M. R. Lamah, N. Y. Haba, and M. Camara, "Frequency of blood groups $\mathrm{ABO}$ and rhesus D in the Guinean population," Transfusion Clinique et Biologique, vol. 14, no. 5, pp. 435-439, 2007.

[6] A. G. Falusi, O. G. Ademowo, C. A. Latunji et al., "Distribution of $\mathrm{ABO}$ and RH genes in Nigeria," African Journal of Medicine and Medical Sciences, vol. 29, no. 1, pp. 23-26, 2000.

[7] Z. A. Randriamanantany, D. H. Rajaonatahina, F. E. Razafimanantsoa et al., "Phenotypic and allelic profile of $\mathrm{ABO}$ and Rhésus D blood group system among blood donor in Antananarivo," International Journal of Immunogenetics, vol. 39, no. 6, pp. 477-479, 2012.

[8] A. Benahadi, R. Alami, and S. Boulahdid, "La distribution des antigènes de groupe sanguins ABO et Rhésus au Maroc," Transfusion Clinique et Biologiqu, vol. 20, no. 3, p. 313, 2013.

[9] N. Agarwal, R. M. Thapliyal, and K. Chatterjee, "Blood group phenotype frequencies in blood donors from a tertiary care hospital in north India," Blood Research, vol. 48, no. 1, pp. 5154, 2013.

[10] M. R. Keramati, H. Shakibaei, M. I. Kheiyyami et al., "Blood group antigens frequencies in the northeast of Iran," Transfusion and Apheresis Science, vol. 45, no. 2, pp. 133-136, 2011.

[11] G. Garratty, S. A. Glynn, and R. McEntire, "ABO and Rh(D) phenotype frequencies of different racial/ethnic groups in the United States," Transfusion, vol. 44, no. 5, pp. 703-706, 2004.

[12] I. Mendel, Bases Immunologiques de la transfusion sanguine, http://efs-alsace.fr/.

[13] G. Daniels, Human Blood Group, John Willey \& Sons, Hoboken, NJ, USA, 2nd edition, 2002.

[14] S. S. Joseph, Contribution à l'étude des groupes sanguins érythrocytaires en Côte d'Ivoire. Inventaire et repartition selon les ethnies [Thèse médecine], Faculté de Médecine, Abidjan, Côte d'Ivoire, 1985.

[15] R. Cabannes, "Hématologie des ethnies de Côte d'Ivoire. Son apport à la connaissance des populations de ce pays," Médecine d’Afrique Noire, vol. 28, pp. 65-72, 1981.

[16] R. Cabannes, A. Senarail, F. Pene, A. Sangare, F. Sombo Mambo, and P. Kple Faget, "Etude hémotypologique des populations de l'afrique de l'Ouest. Référence particulière aux populations ivoiriennes et aux Peulh de l'afrique de l'Ouest," Annales de l'Université d'Abidjan. Série B, Médecine, vol. 13, pp. 11-16, 1979.

[17] M. A. Kahar and R. D. Patel, "Phenotype frequencies of blood group systems (Rh, Kell, Kidd, Duffy, MNS, P, Lewis, and Lutheran) in blood donors of south Gujarat, India," Asian Journal of Transfusion Science, vol. 8, no. 1, pp. 51-55, 2014.

[18] F. F. Wagner, D. Kasulke, M. Kerowgan, and W. A. Flegel, "Frequencies of the blood groups ABO, Rhesus, D category VI, Kell, and of clinical relevant high-frequency antigens in SouthWestern Germany," Infusionstherapie und Transfusionsmedizin, vol. 22, no. 5, pp. 285-290, 1995. 


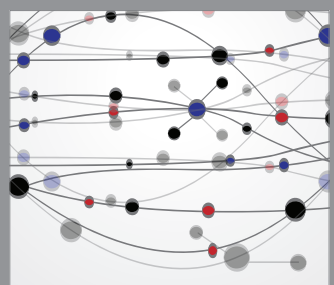

The Scientific World Journal
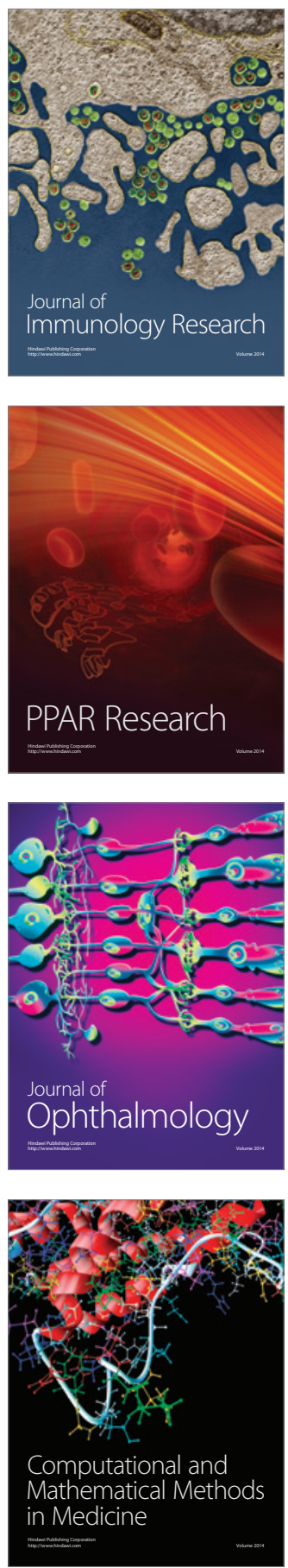

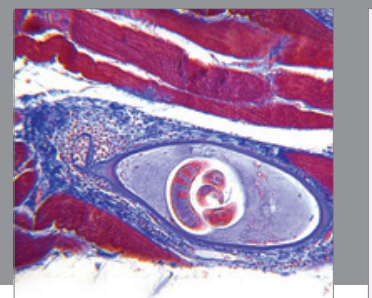

Gastroenterology

Research and Practice
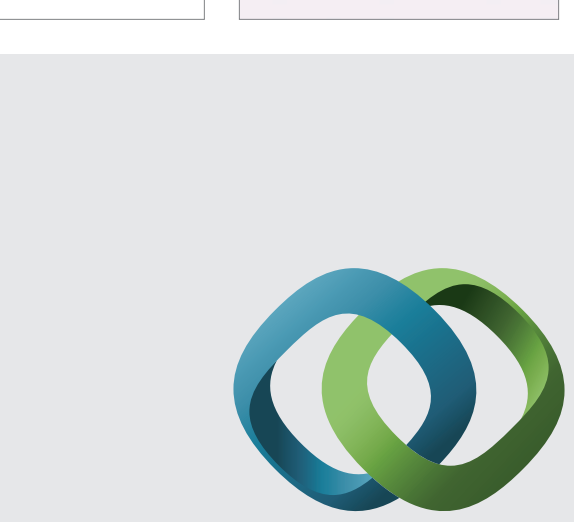

\section{Hindawi}

Submit your manuscripts at

http://www.hindawi.com
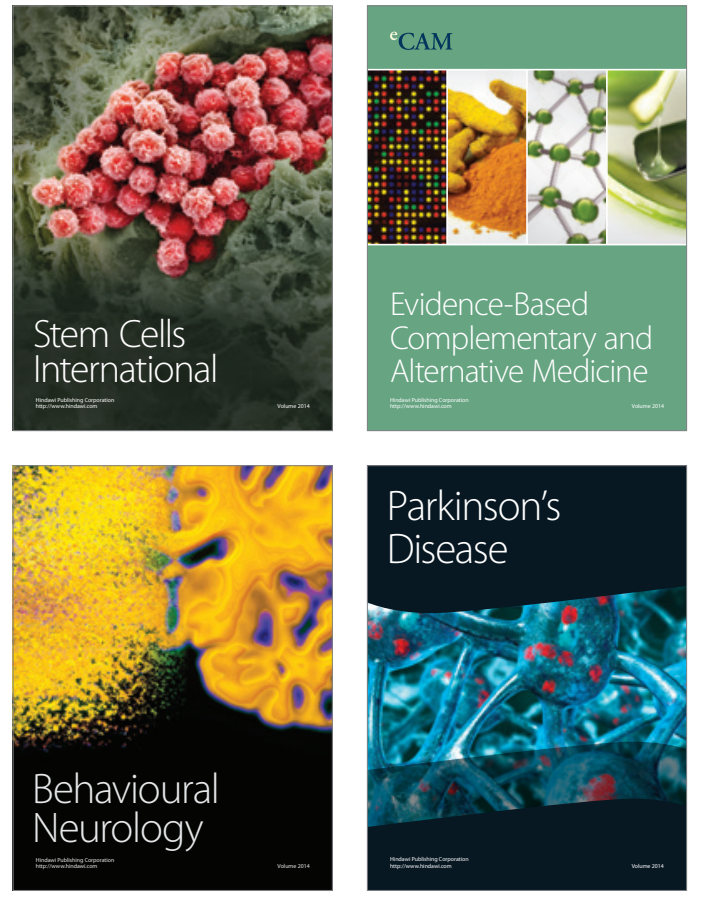
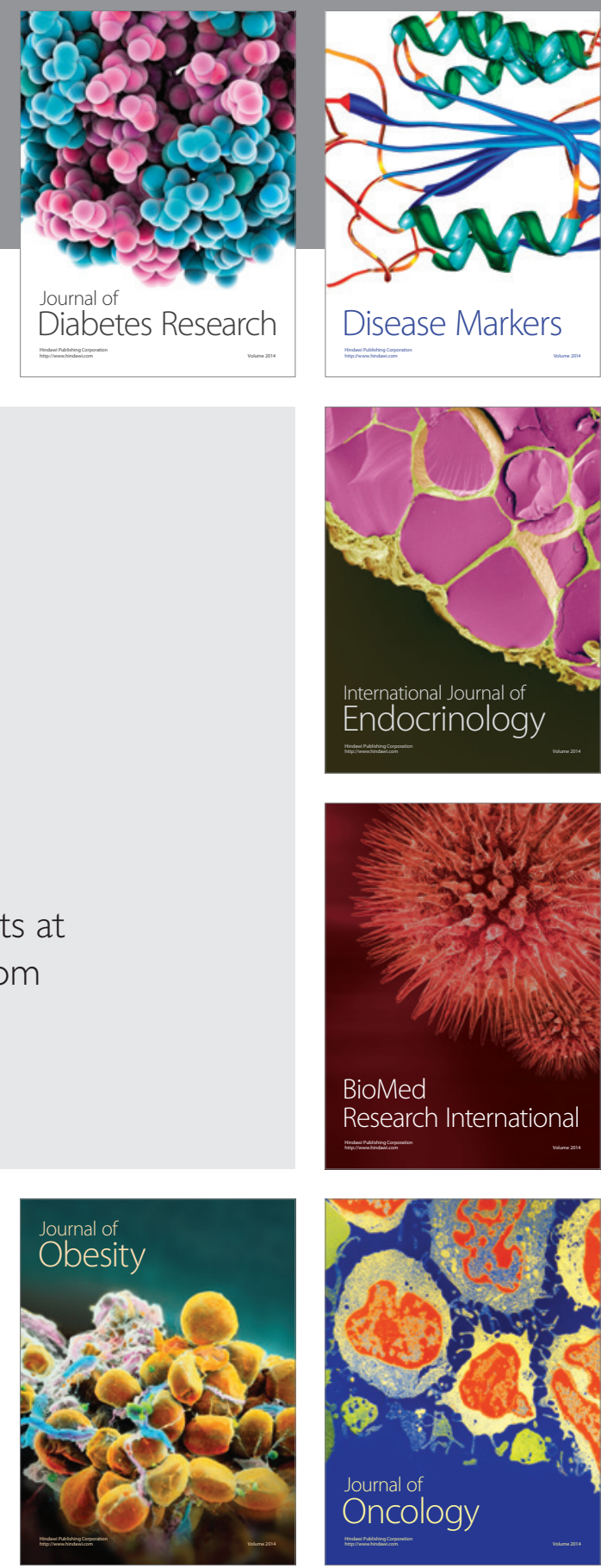

Disease Markers
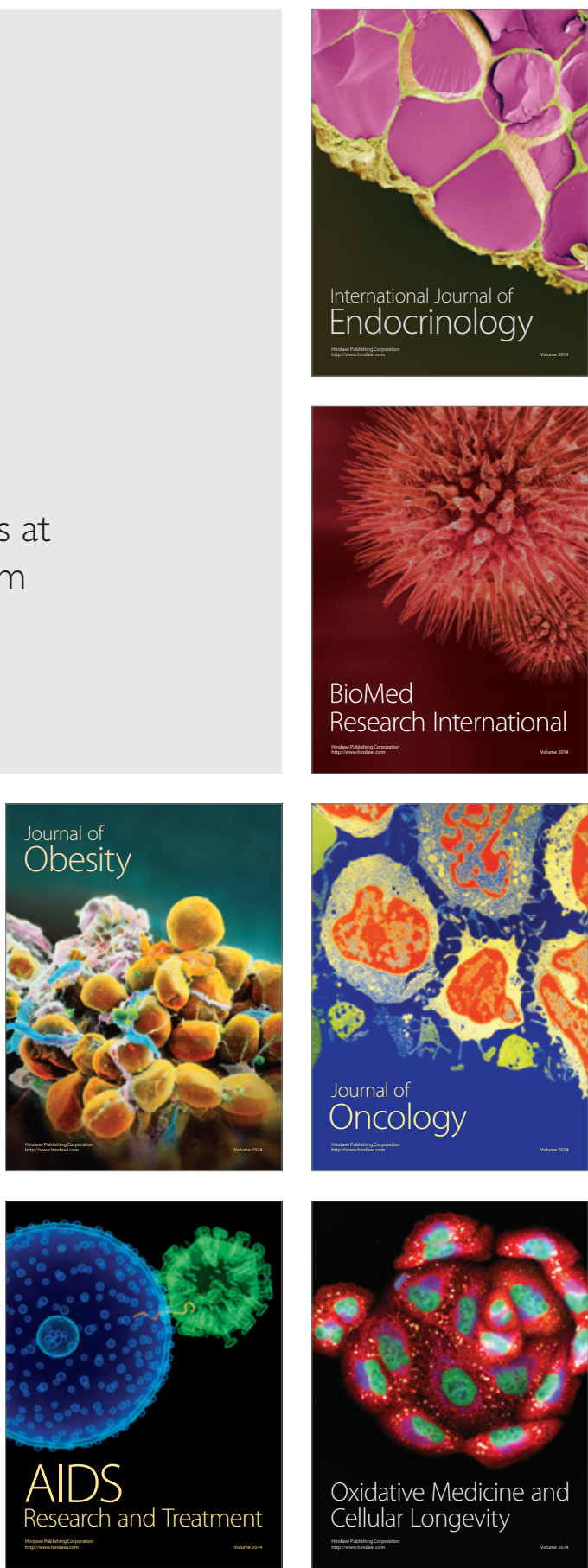